\title{
CORN SUBSTITUTION USING FERMENTED SOLID CASSAVA-WASTE ON BROILER CHICKEN
}

\author{
Ali-Mursyid W. M. ${ }^{1}$, Z. Bachruddin ${ }^{2}$, Zuprizal ${ }^{2}$ and M. Nur-Cahyanto ${ }^{3}$ \\ ${ }^{1}$ Faculty of Agriculture, Veteran Bangun Nusantara University, \\ Jl. Letjen Sujono Humardani No. 1, Sukoharjo 57521, Central Java - Indonesia \\ ${ }^{2}$ Faculty of Animal Husbandry, Gadjah Mada University, Yogyakarta - Indonesia \\ ${ }^{3}$ Faculty of Agricultural Technology, Gadjah Mada University, Yogyakarta - Indonesia \\ Corresponding E-mail: alimursyid_wm@yahoo.com
}

Received October 14, 2009; Accepted December 22, 2009

\begin{abstract}
The objective of the research was to examine unfermented solid cassava-waste (USCW) and fermented solid cassava-waste (FSCW) as the substitution of corn in broiler ration. Two hundred and ten birds of one-week-male broiler chicken were divided into seven kinds of one-way treatment of completely randomized design. Five replications were used for each treatment; there were six chickens in each replication. The substitution levels of corn in broiler ration by USCW and FSCW were 0\% (control), 10, 20, and 30\%. The result showed that corn substitution up to $20 \%$ using USCW and FSCW did not affect the digestibility of feed (DF), digestibility of soluble protein (DSP) and crude protein (DCP), and digestibility of starch (DS). Substitution up to 30\% using FSCW did not affect the DSP and DCP. However, substitution of USCW at the same level decreased DSP, DCP, DF, and DS. Corn substitution up to $20 \%$ using USCW and FSCW did not affect the feed intake (FI), body weight gain (BWG) and feed conversion ratio (FCR). Substitution up to 30\% using FSCW did not affect the BWG and FCR. However, substitution of USCW at the same level decreased BWG and increased FCR. FSCW can be used as a substitute for the corn up to $30 \%$ without affecting the performance and the values of the nutrient digestibility, meanwhile USCW is only able to substitute corn up to $20 \%$.

Keywords: broiler chicken, corn, fermented solid cassava-waste.
\end{abstract}

\section{INTRODUCTION}

Solid cassava waste (SCW) is a solid waste of the cassava starch extraction process in tapioca industries. It will smell acid and unpleasant odor, and pollute the environment when it is left unprocessed. The cassava production reached 16.9 million tons 2002 with the planting area of 1.27 million hectares. Most of the cassava products are sent to the tapioca industries. As a result, the industries produce 1.2 million tons of SCW every year (BPS, 2003).

The main nutritional content of SCW is carbohydrate. Therefore, in terms of production capacity and carbohydrate content, SCW is very potential of poultry feed (Mulyono, 1999). Its high crude fiber, its low protein content, and its low digestibility are of constraints to its usage as the poultry feed matters (Ali-Mursyid and Zuprizal, 2005). The crude fiber is a special nutrient that arranges the plant cell walls. The nutrient mostly is cellulose. The cellulose is D-
Glucose Polymer with $\beta-1,4$ glycoside linkages (Carlile et al., 2001), which cannot be digested by poultry (Santos et al., 2004). The use of such a high cellulose as SCW as a substitute corn at the level of 30\% (Mulyono, 1999) and cassava peelings at the level of 50\% (Salami and Odunsi, 2003) can decrease broiler performance.

The cellulolytic fermentation is a way to deal with the problems of feedstuff that are rich of cellulose. Microbes secrete cellulase enzymes to degrade and transform cellulosic macromolecule to simple molecules which are easily absorbed by cells (Gianfreda and Rao, 2004). The cellulosic degradation of cell walls due to enzymatic hydrolysis causes the cell contents to be released, so that it is easily digested by poultry endogen enzyme (Hetland et al., 2004). Trichoderma AA1 mutant is a microbe which produces cellulases and is resistant to catabolite repression (AliMursyid et al., 2007) which is very potential to be used in the fermentation of such substrate which is rich of cellulose as SCW. 
The fermentation of a feedstuff can increase the content of protein, improve digestibility, and form various amino acids, enzymes, and vitamins (Stanbury et al., 1995). The fermentation of SCW by using the Trichoderma AA1 mutant can increase the content of protein and amino acids, and decrease the content of crude fiber and cellulose (Mulyono et al., 2008). The increase of amino acids due to the fermentation was also reported by Ali-Mursyid and Zuprizal (2005).

The increase of digestibility of dry matter, protein, and metabolized energy is present in SCW which is fermented by the Trichoderma AA1 mutant (Mulyono et al., 2008). Ali-Mursyid and Zuprizal (2005) reported the significant increase in the soluble in-vivo protein digestibility and AME up to nearly $100 \mathrm{kcal} / \mathrm{kg}$ from SCW fermented by A.oryzae.

This research aimed to examine unfermented SCW (USCW) and fermented SCW (FSCW) as the substitution of corn in broiler ration.

\section{MATERIAL AND METHOD}

\section{Chicken and Diet}

The birds used in the research were male broiler of Hubbard strain, aged 1 week. The diets used in this research was composed of several compositions presented in Table 1.

\section{Experimental Design}

Two hundred and ten birds of one-weekmale broiler chicken were divided into seven kinds of one-way treatment of completely randomized design. Five replications were used for each treatment; there were six chickens in each replication. Every repetition placed in a cage with the dimension of $1 \times 1 \times 0.6 \mathrm{~m}^{3}$ whose floor was made of wire mesh, and which was supported by a 40 watt lamp, feeder, and drinker. The substitution levels of corn by USCW and FSCW were $0 \%$ (control), 10, 20, and $30 \%$.

The New Castle Disease vaccination was conducted when the birds were aged 5 days. The feed and drink were given ad libitum. The treatment was conducted for four weeks. Every week, the feed intake and the weight of the birds were measured. The feed intake and the weight of the birds were weighed by using a scale which the capacity was $10 \mathrm{~kg}$, and the accuracy was $0.1 \mathrm{~g}$.

\section{Excreta and Digesta Collection}

Excreta samples were gathered by using the technique modified by Lee et al. (2004). It was conducted for three days (when the broilers were aged 32-34 days). The daily collected excreta was dried under the sunlight for three days, weighed, and ground into powders until they could pass through the $1 \mathrm{~mm}$ sieve. The powders were then mixed evenly, and $20 \mathrm{~g}$ of sub-samples were taken, placed in a sealed plastic bag and kept in a refrigerator with the temperature of $4^{\circ} \mathrm{C}$.

On the 35 days of age, the birds were killed by cervical dislocation. Their ileum digesta were directly collected by gentle stripping. Immediately after obtaining the digesta, the sample were dried in the oven at $60^{\circ} \mathrm{C}$ until their weight was constant. The samples were then kept in a sealed plastic bag and saved in a refrigerator with the temperature of $4^{\circ} \mathrm{C}$.

\section{Value of Nutrient Digestibility and Broiler Performance}

The nutrient contents of the excreta, digesta, and diet were measured in terms of dry matter, crude protein (AOAC, 1990), starch, and soluble protein (Bradford, 1976). The value of nutrient digestibility was calculated in the dry matter base (DM) (Lemme et al., 2004) as follows:

$$
\frac{\text { FI - EX }}{\text { FI }} \times 100
$$

$$
\begin{aligned}
& \text { DSP }=\frac{[\text { FI } \times \text { SP.f }]-[\text { EX x SP. ile }]}{[\text { FI } \times \text { SP.f }]} \times 100 \\
& D C P=\frac{[\text { FI } \times \text { CP.f }]-[\text { EX } \times \text { CP.ile }]}{[\text { FI } \times \text { CP.f }]} \times 100 \\
& D S=\frac{[\text { FI } \times \text { S.f }]-[\text { EX } \times \text { S.eks }]}{[\text { FI } \times \text { S.f }]} \times 100
\end{aligned}
$$

where, $\mathrm{DF}=$ digestibility of feed, DSP = digestibility of soluble protein, $\mathrm{DCP}=$ digestibility of crude protein, DS = digestibility of starch, FI = feed intake (g DM), EX = excretacollected $(\mathrm{g} \mathrm{DM})$, SP.f $=$ soluble protein content of feed $(\% \mathrm{DM})$, SP.ile $=$ soluble protein content of ileum digesta $(\%$ DM $)$, CP.f $=$ crude protein content of feed $(\% \mathrm{DM}), \mathrm{CP} . \mathrm{ile}=$ crude protein content of ileum digesta (\% DM), S.f $=$ starch 
Table 1. Ingredient and Nutrient Composition of the Experimental Diets

\begin{tabular}{lrrrrrrr}
\hline Ingredients & \multicolumn{7}{c}{ Treatments } \\
\cline { 2 - 8 } & Control FSCW 10 & FSCW 20 & FSCW 30 USCW 10 & USCW 20 & USCW 30 \\
\hline Yellow corn & 55 & 49.5 & 44 & 38.5 & 49.5 & 44 & 38.5 \\
FSCW & 0 & 5.5 & 11 & 16.5 & 0 & 0 & 0 \\
USCW & 0 & 0 & 0 & 0 & 5.5 & 11 & 16.5 \\
Rice bran & 12 & 12 & 12 & 12 & 12 & 12 & 12 \\
Soybean meal & 17 & 17 & 17 & 17 & 17 & 17 & 17 \\
Poultry meat meal & 9 & 9 & 9 & 9 & 9 & 9 & 9 \\
Meat bone meal & 5 & 5 & 5 & 5 & 5 & 5 & 5 \\
Palm oil & 1.2 & 1.2 & 1.2 & 1.2 & 1.2 & 1.2 & 1.2 \\
Vit-min-mix & 0.5 & 0.5 & 0.5 & 0.5 & 0.5 & 0.5 & 0.5 \\
NaCl & 0.2 & 0.2 & 0.2 & 0.2 & 0.2 & 0.2 & 0.2 \\
DL-methionine & 0.1 & 0.1 & 0.1 & 0.1 & 0.1 & 0.1 & 0.1 \\
Total & 100 & 100 & 100 & 100 & 100 & 100 & 100 \\
\hline Composition of Nutrients a & & & & & & \\
CP $(\%)$ & 21.73 & 21.4 & 21.08 & 20.76 & 21.32 & 20.9 & 20.49 \\
ME (kcal/kg) & 2982 & 2933 & 2885 & 2836 & 2914 & 2846 & 2777 \\
CF $(\%)$ & 4.07 & 4.48 & 4.89 & 5.29 & 4.65 & 5.22 & 5.79 \\
Starch $(\%)$ & 37.93 & 37.7 & 37.47 & 37.24 & 30.63 & 37.34 & 37.04 \\
Ca $(\%)$ & 0.94 & 0.96 & 0.98 & 0.1 & 0.95 & 0.96 & 0.97 \\
P $(\%)$ & 0.88 & 0.88 & 0.87 & 0.87 & 0.87 & 0.86 & 0.84 \\
\hline
\end{tabular}

${ }^{a}$ Calculation-based,

USCW=Unfermented Solid Cassava Waste, FSCW=Fermented Solid Cassava Waste. Vit-min-mix $=$ Vitamin and mineral premix, $\mathrm{CP}=\mathrm{Crude}$ Protein, $\mathrm{ME}=$ Metabolizable $\mathrm{E}$ $\mathrm{CF}=$ Crude Fiber, $\mathrm{Ca}=$ Calcium, $\mathrm{P}=$ Phosphorus.

content of feed $(\% \mathrm{DM}), \mathrm{S}$. eks = starch content of excreta $(\% \mathrm{DM})$.

The broilers' performance observed included the average of body weight gain (BWG, g/broiler/day), feed intake (FI, g/broiler/day), and feed conversion ratio (FCR).

\section{Statistical Analysis}

Data of the research were analyzed by using one-way Analysis of Variance (ANOVA), and it was continued by Duncan's Multiple Range Test (DMRT) (Gill, 1981).

\section{RESULTS AND DISCUSSION}

\section{Nutrient Digestibility}

The substitution of corn up to $20 \%$ with both USCW and FSCW did not significantly influence the nutrient digestibility of the diets. The influence was significant when the substitution was increased up to $30 \%$ (Table 2).

The value of nutrient digestibility of the feed was closely related to its crude fiber content. The content of crude fiber in FSCW and USCW was respectively 3 and 4 times higher than that of crude fiber in corn (Mulyono et al., 2008), so that the substitution treatment, increased the content of crude fiber in the feed. The increase of crude fiber content due to the substitution of the corn up to the level of $20 \%$ statistically did not decrease the value of nutrient digestibility (DF, DCP, and DS). The crude fiber in the broiler diet was regarded as a factor that could decrease feed digestibility, but it had a beneficial effect at the moderate level. The existence of insoluble fiber in the gizzard stimulated the secretion of bile acids that was responsible for the emulsification of the feed lipid so that the role of the lipid to inhibit the reaction of nutrient and endogen enzyme of the broiler decreased. The bile acids also took role in the proteases enzyme stabilization process that it could prevent autolysis (Hetland et al., 2004) and its activity did not decrease. Such insoluble matter as lupin husk (Brenes et al., 2002) and the 
Table 2. The Effect of Substitution of the Corn with FSCW and USCW towards the Nutr Digestibility

\begin{tabular}{lcccc}
\hline \multicolumn{1}{c}{ Treatments } & $\begin{array}{c}\text { DF ns } \\
(\% \text { DM })\end{array}$ & $\begin{array}{c}\text { DSP } \\
(\% \text { DM })\end{array}$ & $\begin{array}{c}\text { DCP } \\
(\% \text { DM })\end{array}$ & $\begin{array}{c}\text { DS } \\
(\% \text { DM })\end{array}$ \\
\hline Control & $72.74^{\mathrm{b}}$ & $90.33^{\mathrm{cd}}$ & $64.33^{\mathrm{bc}}$ & $90.25^{\mathrm{b}}$ \\
FSCW10 & $71.48^{\mathrm{b}}$ & $89.46^{\mathrm{cd}}$ & $66.62^{\mathrm{c}}$ & $88.80^{\mathrm{ab}}$ \\
FSCW20 & $73.10^{\mathrm{ab}}$ & $88.95^{\mathrm{bc}}$ & $67.20^{\mathrm{c}}$ & $89.87^{\mathrm{b}}$ \\
FSCW30 & $69.78^{\mathrm{a}}$ & $87.56^{\mathrm{b}}$ & $59.84^{\mathrm{bc}}$ & $87.59^{\mathrm{a}}$ \\
USCW10 & $70.86^{\mathrm{b}}$ & $88.70^{\mathrm{bc}}$ & $59.35^{\mathrm{bc}}$ & $88.87^{\mathrm{ab}}$ \\
USCW20 & $74.17^{\mathrm{b}}$ & $90.76^{\mathrm{d}}$ & $68.24^{\mathrm{c}}$ & $90.33^{\mathrm{b}}$ \\
USCW30 & $69.25^{\mathrm{a}}$ & $83.94^{\mathrm{a}}$ & $53.67^{\mathrm{a}}$ & $87.99^{\mathrm{a}}$ \\
\hline
\end{tabular}

abcd The different superscript in the same column indicate the differ significantly $(\mathrm{P}<0.0$ ؛

$\mathrm{DF}=$ digestibility of feed, DSP = digestibility of soluble protein,

DCP $=$ digestibility of crude protein, DS = digestibility of starch

addition of sawdust up to $4 \%$ in the broiler feed would increase the weight of gizzard and fiber quantity without affecting the starch digestibility (Hetland et al., 2004).

The increase level of corn substitution up to $30 \%$ caused the decrease in the nutrient digestibility $(\mathrm{P}<0.05)$. In such a level, the use of FSCW and USCW increased the content of crude fiber above $5 \%$ (Table 1). The increase of the crude fiber (as indigestible matter) in the broiler feed would reduce the portion of other more easily digested nutrients. This indicated that the quality of feed decreased. The too high decrease in the quality of the feed would affect its digestibility value. The use of insoluble fiber also caused the transit time of digesta in the digestive tract faster (Wang et al., 2004). As a result, the time for digestion process was less. Besides, there was a decrease in the absorption level due to the inhibition of nutritional access towards intestine epithel. The inhibition was caused by the digesta viscosity (Santos et al., 2004). The corn substitution with the cassava waste improved the digesta viscosity because the corn starch viscosity was lower than the cassava viscosity (Whistler and Be Miler, 1997).

Eventhough the level of corn substitution with FSCW was increased up to $30 \%$, the value of DCP and DSP did not decrease $(\mathrm{P}>0.05)$. The difference of effect between FSCW and USCW to substitute the corn was due to the fact that the protein digestibility of FSCW was higher than of the USCW (Mulyono et al., 2008). Fermented SCW had a higher digestibility because the intracellular protein protected by the protein cell walls was released during the fermentation due to the microbial cellulase activity (Kocher et al., 2000).

\section{Broiler Performance}

The broiler performance showed that the corn substitution with FSCW and USCW had a significant effect $(\mathrm{P}<0.05)$ on Body Weight Gain (BWG) and Feed Conversion Ratio (FCR), but did not have a significant effect on the feed intake (FI) (Table 3).

The corn substitution up to the level of $20 \%$ with FSCW and USCW did not have an effect $(\mathrm{P}>0.05)$ on BWG and FCR, yet the corn substitution up to $30 \%$ had a significantly different effect. In such a level, the use of FSCW to substitute the corn statistically still resulted in the equivalent values of BWG and FCR with those of control group, but the use of USCW to substitute the corn statistically resulted in the lower values $(\mathrm{P}<0.05)$ of $\mathrm{BWG}$ and $\mathrm{FCR}$ than those of control group.

The ability of FSCW and USCW to substitute the corn up to the level of $20 \%$ could be explained in terms of the content of starch and nitrogen free extract (NFE), its role as the insoluble fiber source, and effect of corn niacitin. The content of starch and NFE in FSCW (starch: 62.04\%; NFE 82.03\%) and in USCW (starch: 62.12\%; NFE; $80.80 \%$ ) was relatively high (AliMursyid et al., 2008), therefore, FSCW and USCW could be potential energy sources to substitute corn. Furthermore, FSCW and USCW had a positive role as the insoluble fiber sources at the moderate level. Their role as an insoluble fiber sources in gizzard could stimulate the secretion of bile acids which emulsified lipid to form micelle 
Tabel 3. The Effect of Substitution of the Corn with FSCW and USCW towards Broiler Performance

\begin{tabular}{lccc}
\hline \multicolumn{1}{c}{ Treatments } & $\begin{array}{c}\text { BWG } \\
(\mathrm{g} / \mathrm{bird} / \text { day })\end{array}$ & $\begin{array}{c}\text { FI } \\
(\mathrm{g} / \mathrm{bird} / \text { day })\end{array}$ & FCR \\
\hline Control & $43.16^{\mathrm{ab}}$ & 90.24 & $2.10^{\mathrm{a}}$ \\
FSCW10 & $46.48^{\mathrm{b}}$ & 93.91 & $2.02^{\mathrm{a}}$ \\
FSCW20 & $45.73^{\mathrm{b}}$ & 95.83 & $2.10^{\mathrm{a}}$ \\
FSCW30 & $44.26^{\mathrm{ab}}$ & 95.18 & $2.16^{\mathrm{ab}}$ \\
USCW10 & $44.92^{\mathrm{b}}$ & 94.14 & $2.10^{\mathrm{a}}$ \\
USCW20 & $45.47^{\mathrm{b}}$ & 94.93 & $2.09^{\mathrm{a}}$ \\
USCW30 & $39.84^{\mathrm{a}}$ & 90.59 & $2.28^{\mathrm{b}}$ \\
\hline
\end{tabular}

ab The different superscript in the same column indicate the differ signific:

ns indicates insignificant difference.

and increase reflux. Micelle was a substance which was soluble in the water so that the nutrient solubility in the intestine lumen increased and its opportunity to react with digestive enzyme also increased (Hetland et al., 2004). The nutrient solubility was the determining factor for the nutrient availability as a substrate in the digestion process. The reflux of gastro-intestinal liquid increased the concentration of digestive enzyme so that it became the determining factor for the nutrient availability.

The constant values of BWG and FCR despite the corn substitution up to $20 \%$ with low quality ingredient could be explained by the reduction of corn portion in the diet. The use of corn in a big quantity resulted in a constraint that it would produce niacitin, and restricting amino acids as methionine, lysine, and tryptophan (Anonym, 2006). The reduction of corn portion would reduce the effect of the niacitin and tryptophan constraint. Niacitin was a complex substance which was formed by the reaction of corn niacin with other substances (Lehninger, 1982). It could not be digested and absorbed, so that this could result in niacin deficiency, that is, it inhibited the growth of bird whose diet was dominated by corn (Noor, 1992). Tryptophan deficiency in corn diet would worsen the effect of the niacin deficiency. Since tryptophan was a substance which could be used in the niacin synthesis. The symptom of restricting amino acid deficiency including tryptophan affected broiler growth and the feed efficiency (Lumpkins et al., 1987), which could be found in the broiler feed that was mainly made from corn and soybean meal (Moore et al., 2003).

The increase of corn substitution up to $30 \%$ with FSCW statistically still resulted in equivalent values of BWG and FCR compared to those of control group, whereas the increase of the corn substitution with USCW had lower values $(p<0.05)$ than those of control group. The fermentation of SCW with Trichoderma AA1 mutant was able to increase the contents of protein, amino acids, lipid, calcium, and phosphorus, but it was able to decrease the cellulose and crude fiber. Besides, it also increased the digestibility values of dry matter, protein, and metabolized energy availability (Mulyono et al., 2008). The degradation of cell wall cellulose during the fermentation would increase glucose, and at the same time release the nutrient of the cell contents ( $\mathrm{Li}$ et al., 2004) so that it could be reached by the endogen enzyme of bird (Chesson, 2000). It was estimated to be the main factor why FSCW could substitute up to $30 \%$ of the corn without affecting BWG and FCR.

The difference of ability between FSCW and USCW to substitute corn towards the parameter of FCR was related to the characters of FSCW and USCW. The digestibility values of dry matter, protein, metabolized energy availability of FSCW was higher than those of USCW (Mulyono, et al., 2008). FSCW had a lower content crude fiber than USCW (Mulyono et al., 2008). Corn substitution up to $30 \%$ of USCW made the crude fiber content too high, and it was presumed to have exceeded the broiler tolerance limit, and had negative effect on broiler. The insoluble fiber in broiler feed caused the transit time of digesta decreased so that the action of the digestive enzyme to digest the nutrient also lower (Choct, 2002).

The factor of viscosity could also be explained the excellence of FSCW ability 
compared to that of USCW ability in corn substitution. The action of microbial cellulase during the fermentation was able to lower the viscosity of a matter, so that the viscosity of FSCW was presumably lower than that of USCW. The high viscosity of a matter in the digestive tract lowered the digestibility and absorption level of nutrient (Choct, 2002). The intestine lumen with a high viscosity reduced the opportunity of digestive enzymes action towards the nutrient ( $\mathrm{Li}$ et al., 2004). Those were the reasons why FSCW could be used in a bigger portion in the broiler feed compared to USCW to substitute corn.

The result of this research was the same as those of several researchers on the use of fermented feedstuff. Corn in the male broiler feed could be substituted up to $15 \%$ with fermented feed with $A$. oryzae without affecting the broiler performance (Mulyono, 1999). Salami and Odunsi (2003) reported that half substitution of corn feed with fermented cassava peelings did not decrease bird performance, but that of some corn feed with the unfermented ones did.

The corn substitution with FSCW and USCW at all level did not have a significant effect $(\mathrm{P}>0.05)$ on the feed intake. This finding was not compatible with the general theory about the feed intake. It was speculated to have relation to the palatability between the corn feed with FSCW and the one with USCW. Corn is a feed matter which is palatable, but FSCW and USCW are feedstuff which are not liked by chicken. SCW is a cassava waste of the cassava starch extraction process. It contains a high crude fiber so that it is not palatable. The feed intake might increase, but it was not significant. This finding was similar to the one by Salami and Odunsi (2003) that the substitution of corn with the unfermented cassava peelings and fermented cassava peelings did not increase feed intake. Furthermore, another factor that could explain the result of this research was the ability of the fiber to absorb water in the digestive tract (Choct, 2002). The absorption of water by the insoluble fiber caused the digesta to be dense and could result in satiety sensation.

\section{CONCLUSION}

Fermented SCW can be used as a substitute for corn up to $30 \%$ without affecting the performance and the values of the nutrient digestibility, meanwhile USCW is only able to substitute corn up to $20 \%$.

\section{ACKNOLEDGMENTS}

We extend our deepest gratitude to the Directorate General of Higher Education, and the Ministry of National Education of the Republic of Indonesia which have funded this research through Program Penelitian Hibah Bersaing XIV/3 Year 2008.

\section{REFERENCES}

Ali-Mursyid, W.M., M. Nur-Cahyanto, Sardjono, Zuprizal, dan Z. Bachruddin. 2007. Mutasi Trichoderma sp. untuk meningkatkan sekresi selulase. Media Kedokteran Hewan. 22:68-73.

Ali-Mursyid, W.M. dan Zuprizal. 2005. Fermentasi substrat padat pada onggok dengan Aspergillus oryzae: evaluasi kandungan protein dan asam amino, kecernaan dan ketersediaan energi pada ayam broiler. Buletin Peternakan. 29:71-78.

AOAC. 1990. Official Methods of Analysis. 15th ed. Association of Official Analytical Chemists. Washington, D.C.

BPS. 2003. Produksi Tanaman Padi dan Palawija di Indonesia. Biro Pusat Statistik. Jakarta.

Bradford M.M. 1976. A rapid and sensitive method for the quantitation of microgram quantities of protein utilizing the principle of protein-dye binding. Analytical Biochem. 72:248-254.

Brenes, A., R.R. Marquardt, W. Guenter, and A. Viveros. 2002. Effect of enzyme addition on the performance and gastrointestinal tract size of chicks fed lupin seed and their fraction. Poult. Sci. 81:670-678.

Carlile, M.J., S.C. Watkinson and G.W. Gooday. 2001. The Fungi. $2^{\text {nd }}$ ed. Academy Press. London - California.

Choct, M. 2002. Non-starch polysaccharides: effect on nutritive value. In Boorman. Poultry Feedstuffs: Supply, Composition and Nutritive Value (McNab, J.M., eds). $\mathrm{CAB}$ International.

Gianfreda, L. and M.A. Rao. 2004. Potential of extra cellular enzymes in remediation of polluted soils: a review. Enzyme Microb Tech. 35:339-354.

Gill, J.L. 1981. Design and Analysis of Experiments in The Animal and Medical Sciences. Volume 1. Iowa State University Press. Ames, Iowa.

Hetland, H.,M. Choct and B. Svihus. 2004. Role 
of insoluble non-starch polysaccharides in poultry nutrition. World's Poult. Sci. J. 60:415-422.

Kocher, A., M. Choct, M.D. Porter, and J. Broz. 2000. The effects of enzymeaddition to broiler diets containing high concentrations of canola or sunflower meal. Poult. Sci. 79:1767-1774.

Lee, K.-W., H. Everts, H.J. Kappert, H. Wouterse, M. Frehner and A.C. Beynen. 2004. Cinnamaldehyde, but not thymol, counteracts the carboxymethyl celluloseinduced growth deppression in female broiler chickens. Int. J. Poult. Sci. 9:608612.

Lehninger, A.L. 1982. Principles of Biochemistry. Terjemahan Thenawidjaja, M. Worth Publisher, Inc.

Lemme, A., V. Ravindran and W.L. Bryden. 2004. Ileal digestibility of amino acids in feed ingridients for broilers. World's Poult. Sci. J. 60:423-437.

Li, W.F., J.Y. Sun and Z.R. Xu. 2004. Effects of NSP degrading enzyme on in vitro digestion of barley. Asian-Aust. J. Anim. Sci. 17:122-126.

Lumpkins, B.S., A.B. Batal and D.H. Baker. 2007. Variations in the digestible sulfur amino acid requirement of broiler chickens due to sex, growth criteria, rearing environment, and processing yields characteristics. Poult. Sci.86:325-330.

Moore, D.T., K. Baker, K. Thompson, E. Blair and J.D. Firman. 2003. Digestible sulfur amino acid requirement of male Turkeys during the 12 to 18 week period. Int. J. Poult. Sci.., 8:38-43.

Mulyono, A.M.W. 1999. Nilai onggok-fermentasi dalam ransum ayam broiler. Tesis. Program Pascasarjana, Universitas Gadjah Mada. Yogyakarta.

Mulyono, A.M.W., Z. Bachruddin, Zuprizal, dan M.N. Cahyanto. 2008. Nilai nutritif onggok-terfermentasi Mutan Trichoderma AA1 pada ayam broiler. Media Kedokteran Hewan 24:165-170.

Noor, Z. 1992. Senyawa Anti Gizi. Pusat Antar Universitas - Pangan dan Gizi Universitas Gadjah Mada. Yogyakarta.

Salami, R.I. and A.A. Odunsi. 2003. Evaluation of processed cassava peal meals as substitutes for maize in the diets of layers. Int. J. Poult.Sci. 8:112-116.

Santos, Jr.A.A., P.R. Ferket, J.L. Grimes and F.W. Edens. 2004. Diatery pentosanase supplementation of diets containing different qualities of wheat on growth performance and metabolizable energy of turkey poults. Int. J. Poult. Sci. 9:33-45.

Stanbury, P.F., A. Whitaker, and S.J. Hall. 1995. Principles of Fermentation Technology. $2^{\text {nd }}$ ed. Butterworth-Heinemann. Oxford.

Sudarmadji, S., B. Haryono dan Suhardi. 2004. Prosedur Analisa untuk Bahan Makanan dan Pertanian. Penerbit Liberty. Yogyakarta.

Wang, J.F., Y.H. Zhu, D.F. Li, H. Jorgensen, and B. Jensen. 2004. The influent of fiber and starch types on nutrient balance and energy metabolism in growing pigs. Asian-Aust. J. Anim. Sci. 17:263-270.

Whistler, R.L. and N. BeMiller. 1997. Carbohydrate Chemistry for Food Scientists. American Association of Cereal Chemists, Inc. St. Paul, Minnesota. 